\title{
IMPLEMENTATION OF SEMI-EMPIRICAL MODELS TO ENHANCE THE ACCURACY OF PANEL METHODS FOR DRAG PREDICTION AT SUPERSONIC SPEEDS
}

\author{
A. Sh. MAhDi Al-ObAidi \\ Senior Lecturer, Taylor's University, Taylor's Lakeside Campus, No. 1 Jalan Taylor's, \\ 47500 Subang Jaya, Selangor DE, Malaysia. \\ abdulkareem.mahdi@taylors.edu.my
}

\begin{abstract}
This paper introduces an attempt to enhance the accuracy of panel methods. A low-order panel method is selected and coupled with semi-empirical methods to enhance the accuracy of drag prediction of flying bodies at supersonic speeds. The semi-empirical methods are used to improve the accuracy of drag prediction by mathematical modelling of viscosity, base drag, and drag due to wing-body interference. Both methods were implemented by a computer program and validated against experimental and analytical results. The comparisons show that a considerable improvement has been achieved for the selected panel method for prediction of drag coefficients. In general, accuracy within an average value of $-4.4 \%$ was obtained for the enhanced panel method. Such accuracy could be considered acceptable for the preliminary design stages of supersonic flying bodies such as projectiles and missiles. The developed computer program gives satisfactory results as long as the considered configurations are slender and the angles of attack are small (below stall angle).
\end{abstract}

ABSTRAK: Kertas kerja ini memperkenalkan percubaan untuk mempertingkatkan ketepatan kaedah panel. Kaedah panel tertib rendah telah dipilih dan digabungkan dengan kaedah separa empirik untuk mempertingkatkan ketepatan ramalan seret objek terbang pada kelajuan supersonik. Kaedah semi empirikal yang digunakan untuk meningkatkan ketepatan jangkaan seret menggunakan model matematik bagi kelikatan, seretan dasar, dan seretan disebabkan oleh badan sayap interferens. Kedua-dua kaedah dijalankan menggunakan program komputer dan disah berdasarkan keputusan uji kaji dan analisis. Perbandingan keputusan menunjukkan peningkatan yang mendadak diperolehi melalui kaedah panel yang telah dipilih sebagai jangkaan pekali seret. Secara umumnya, ketepatan yang melingkungi nilai purata sebanyak $-4.4 \%$ telah diperolehi daripada kaedah peningkatan panel. Keputusan sebegini boleh diterima untuk peringkat reka bentuk permulaan bagi objek terbang supersonik seperti projektil dan misil. Program komputer yang direka memberikan keputusan yang memuaskan selagi konfigurasi yang dipilih adalah kecil dan sudut serangan adalah rendah (di bawah sudut tegun).

KEYWORDS: panel methods; semi-empirical methods; drag coefficient; supersonic speeds; wing-body configuration. 


\section{INTRODUCTION}

The determination of aerodynamic characteristics of flight-vehicles has traditionally been relegated to the wind tunnel (experimental methods) or estimates from basic theory (theoretical methods). Wind tunnel tests are costly, time consuming and require both constructions of a model and an adequate test facility. Additionally, the lag time between the paper design and the wind tunnel results can be considerable. Furthermore, any configuration change requires a change of the test model.

The existing purely theoretical methods were initiated from the compressible form of the Navier-Stokes equations. Considering the limits on the available computer power and the cost of calculations, one has to make a trade-off between the complexity of the mathematical model and the complexity of the geometric configuration that can be treated. This is illustrated in Fig. 1 [1]. If the flow is assumed steady, irrotational, and inviscid then it is possible to introduce a velocity potential and the full Navier-Stokes equations reduce to the potential flow equation [2].

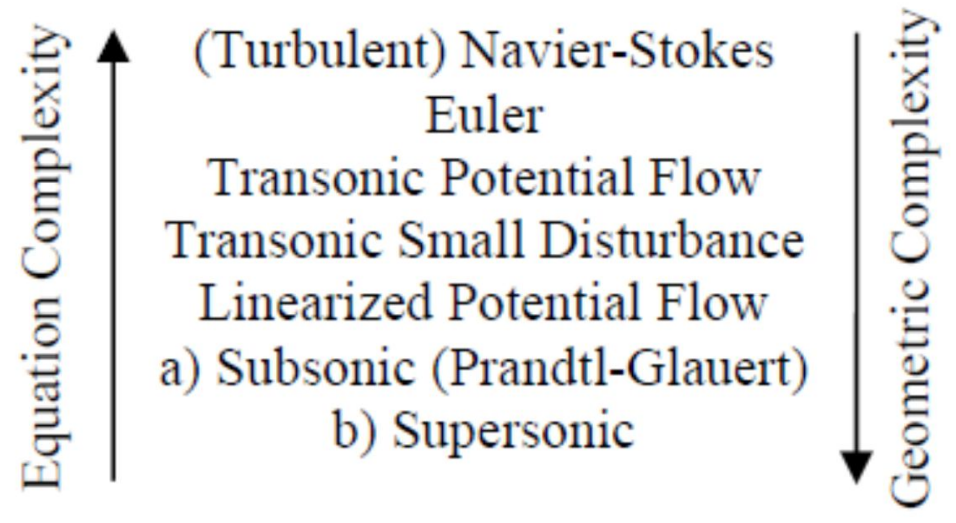

Fig. 1: Hierarchy of mathematical models [1].

During recent years, both computer power and numerical algorithm efficiency are simultaneously improved. As a consequence, numerical methods have been developed sufficiently to initiate some changes in traditional methods of aerodynamic design [3]. Panel method, as one of numerical methods, has the advantage that the dimensionality is reduced (it only requires specification of the boundaries). The advantage of reducing the dimension of the problem gives a priority of special application in the early stages of design. However, they still have a reputation for being inaccurate or unreliable with respect to drag [4]. The latest codes being used currently are higher-order methods based, instead of the low-order method being used in the codes of the past.

The application of numerical techniques allows the treatment of more realistic geometries of flight-vehicles. Panel methods are traditionally based on assumption of potential flow. These methods usually follow the classical steps of potential flow numerical solutions; selection of singularity element, aerodynamic representation, discretization of geometry, calculation of the normal velocity at the control point, formation and solution of the boundary condition equations, and calculation of pressures, forces, and moments [5]. Thus, the panel methods are 
efficiently employed for the computation of lift and moments in an inviscid flow; they cannot capture the viscous effects.

In a real fluid at supersonic speeds the total drag force is usually considered to be of three components; skin friction drag, wave drag, and base drag. Of these components only the wave drag can be computed using panel methods. At low supersonic speeds for a body-alone configuration the skin friction drag and base drag about $60 \%$ of the total drag [6]. This indicates that panel methods (based on potential flow) can capture only $40 \%$ of the total drag of flight-vehicles at supersonic speeds.

In the present work, a classical low-order panel method is selected and coupled with semi-empirical methods to improve the accuracy of drag prediction for flying slender bodies (such as missiles, projectiles, etc.) at supersonic speeds. Briefly, the semi-empirical methods are used to model:

(1) the effect of viscosity to calculate the skin friction drag,

(2) the effect the base drag, and

(3) the drag due to wing-body interference.

\section{PREVIOUS WORK}

There are many works to calculate the drag using semi-empirical methods. Moore [7] combined several theoretical and empirical procedures to calculate lift, drag, and center of pressure on wing-body-tail configurations from Mach 0 to about 3 and for angles of attack to about $15^{\circ}$. Body and wing geometries could be quite general in that pointed or blunt nose bodies and sharp or blunt leading-edge wings could be assumed. Comparison of this method with experiment for several configurations indicates that accuracies of $\pm 10 \%$ could be obtained for force coefficients of most configurations.

Erickson [8] discussed in his report panel-method capabilities and limitations, basic concepts common to all panel-method codes, different choices that have been made in the implementation of these concepts into working computer programs, and various modelling techniques involving boundary conditions, jump properties, and trailing wakes. An approach for extending the method to nonlinear transonic flow was also presented.

Increasing the accuracy of numerical methods in predicting the drag by implementation of semi-empirical methods attracted many researchers. Van Dam [9] reviewed recent experiences in CFD-based drag prediction with an emphasis on flow solutions governed by the Euler and Reynolds-averaged Navier-Stokes equations. The review demonstrates that although significant progress has been made, CFD-based drag prediction still faces a number of hurdles that must be dealt with before it will become more widely accepted.

Coiro and Nicolosi [10] developed a number of numerical and experimental tools devoted to aircraft design for low subsonic flows. These tools comprise numerical codes for analysis, design and simulation, and experimental tests performed in a wind tunnel particularly devoted to light aircraft design.

Voskuij1 [11] used the analysis tool called VSAERO [12], which implements a first order panel method, extended with several features such as an integral viscous boundary layer, Prandtl-Glauert correction for high Mach numbers and a Trefftz plane analysis to calculate the induced drag. 
As clearly seen from this review the problem of drag prediction was attacked partially. The current paper attempts to predict all components of the drag by using both methods; numerical and semi-empirical. Such a combined method becomes a very powerful tool especially when accurate drag prediction is required for non-conventional flight-vehicle configurations, such as space shuttle, multistage missiles, blended wing body aircraft, etc.

\section{METHODS OF ANALYSES}

\subsection{Panel Methods}

Panel-method-based computer programs are currently the workhorse codes for predicting the aerodynamics of complete configurations [8]. A representative flight-vehicle example that has been analyzed with panel method codes is shown in Fig. 2. The equation that panel codes solve is the Prandtl-Glauert equation.

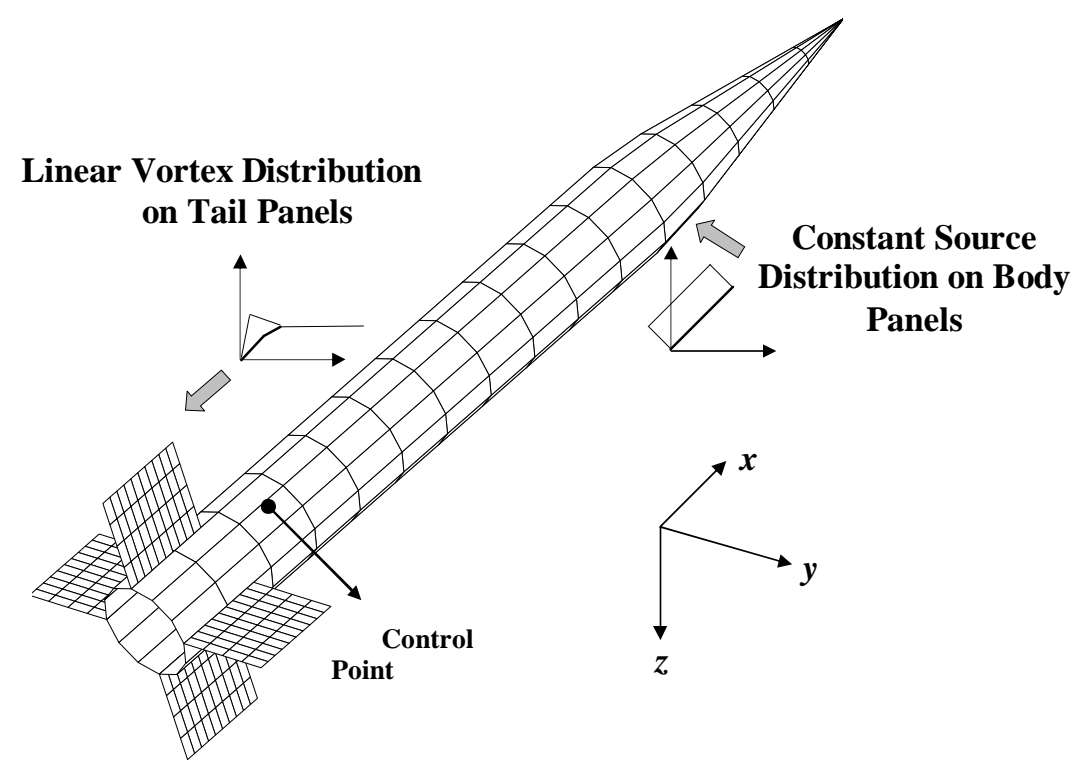

Fig. 2: Aerodynamic representation used in panel method.

For steady supersonic flow this equation is usually written as:

$$
\left(M_{\infty}^{2}-1\right) \phi_{x x}-\phi_{y y}-\phi_{z z}=0
$$

where $M_{\infty}$ is the free-stream Mach number and $\phi$ is the perturbation velocity potential [13]. Eq. (1) is hyperbolic, with the $x$-derivative term behaving like time in the wave equation.

A general solution to Eq. (1) is given by Heaslet et al. [14], based on Volterra's solution of the two-dimensional wave equation. This result was repeated by Woodward and Larsen [15] and gave, in integral form, the value of $\phi$ at any point due to a small perturbation of the flow originating on a surface.

The numerical method used by Carmichael and Woodward [16] replaced the actual wingbody combination by distributions of singularities, which satisfy the linearized equation of 
supersonic flow, Eq. (1), whose strengths are adjusted to satisfy the boundary conditions required by the geometry of the particular configuration. The wing warp and incidence are represented by distributions of vorticity corresponding to pressure differences across the wing. The wing thickness effect is given by sources and sinks located over the wing reference plane. The body thickness, camber, and incidence are simulated by line sources and doublets placed along the body reference axis. Finally, the interference effects of the wing on the body are cancelled by a distribution of vorticity on the surface of the body.

This numerical procedure has been programmed for automated computation for a great variety of configurations. Thus many codes have been developed. Kay et al. [17] provide a brief description of the codes aerodynamicists will most likely encounter. Although such codes are routinely used to analyze very complicated geometries, they do so at the expense of ignoring much fluid physics.

The Prandtl-Glauert equation is the simplest form of the fluid-flow equations that contain compressibility effects (i.e., the effect of Mach number on fluid density). It is obtained from the more general Navier-Stokes equation by:

(1) neglecting all the viscous and heat-transfer terms;

(2) assuming that the flow is irrotational, thereby admitting the introduction of a velocity potential; and

(3) discarding all nonlinear terms.

This restricts the flow to be inviscid, irrotational, and linear. Often, the flow is also assumed to be steady. Physically, these restrictions mean that important flow behavior such as separation, skin-friction drag, base drag, and transonic shocks are not predicted with panel methods. Items that are predicted include drag due-to-lift (often called induced drag for subsonic flow, and vortex drag for supersonic flow), and wave drag [8].

\subsection{Semi-empirical Methods}

The current paper uses a panel method in combination with semi-empirical methods to approximately account for additional fluid physics neglected by the Prandtl-Glauert equation. Semi-empirical methods are used to model

(1) the effect of viscosity to calculate the skin friction drag;

(2) the effect the base drag;

(3) the drag due to wing-body interference.

\subsubsection{Effect of Viscosity}

The effect of viscosity can be partially modelled through the calculation of skin friction drag coefficient using a boundary layer solution. The skin friction drag coefficient $C_{D f r}$ of a wing-body configuration is the sum of the skin friction drag coefficient of the body $\left(C_{D f r}\right)_{\mathrm{B}}$ and the skin friction drag coefficient of the wing $\left(C_{D f r}\right)_{W}$

$$
C_{D f r}=\left(C_{D f r}\right)_{B}+\left(C_{D f r}\right)_{W}
$$

The general approach of calculating skin friction drag coefficient is by estimating the skin friction coefficient of a flat plate in an incompressible flow [18, 19], and then this coefficient is corrected according to the body wetted area and compressibility effect [20].

a) Body Skin Friction Drag Coefficient, $\left(C_{D f r}\right)_{B}$ 
For fully-turbulent and compressible flow, the friction coefficient is given by

$$
\begin{aligned}
& \left(C_{D f r}\right)_{B}=\left(C_{f}\right)_{B} \frac{\left(S_{\text {wet }}\right)_{B}}{S_{r e f}} \\
& \left(C_{f}\right)_{B}=\frac{0.455\left(\log _{10} \operatorname{Re}_{B}\right)^{-2.58}}{\left(1+0.21 M_{\infty}^{2}\right)^{0.467}} \\
& \operatorname{Re}_{B}=\frac{l_{r e f} V_{\infty}}{v_{\infty}}
\end{aligned}
$$

In the present work, the influence of surface roughness on the skin friction drag is neglegted. Thus, the Reynolds number based on body length (or wing mean aerodyanmic chord) and Mach number is used for further calculations.

The influence of surface roughness can be determined according to the methodology described in the USAF-DATCOM [21], whereby a so-called cut-off Reynolds number is used to determine if surface roughness has an influence on the friction coefficient. The Reynolds number based on a reference length and Mach number is compared with the cut-off Reynolds number and the smaller is used for further calculations.

\section{b) Wing Skin Friction Drag Coefficient, $\left(C_{D f r}\right)_{W}$}

At supersonic speeds, the skin friction drag coefficient for wings is given in [22] by

$$
\left(C_{D f r}\right)_{W}=\left(C_{f}\right)_{W} \eta_{t} \frac{\left(S_{w e t}\right)_{W}}{S_{r e f}}
$$

where $\left(C_{f}\right)_{W}$ is the skin friction coefficient of wing, which is given by Eq. (4) with Reynolds number based on the wing mean aerodynamic chord $c_{M A C}$

$$
\operatorname{Re}_{W}=\frac{c_{M A C} V_{\infty}}{v_{\infty}}
$$

Eq. (4) is applicable for ranges of Reynolds number $2 \times 10^{6}<\operatorname{Re}<10^{10}$ and $M_{\infty} \leq 4$, as this is the limitation given by the Prandtl-Schlichting universal formula $[18,19]$.

$\eta_{t}$ is the factor for the wing thickness effect. This factor takes into account that the actual wing is not a flat plate and is given by Fig. 3 [23] as a function of the relative maximum thickness of the wing profile $\bar{t}_{\max }$

$$
\bar{t}_{\max }=\frac{t_{\max }}{c_{M A C}}
$$




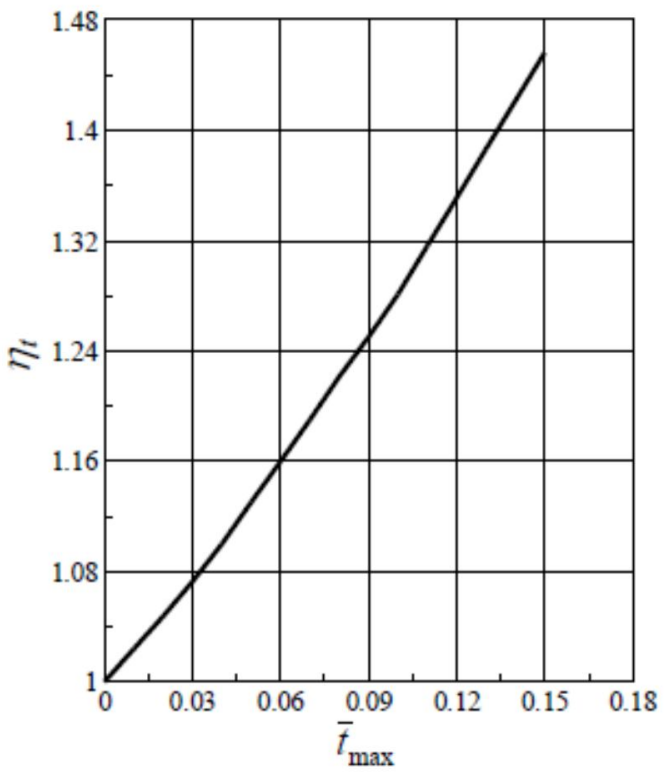

Fig. 3: Effect of profile thickness [23].

\subsubsection{Base Drag}

At supersonic speeds the base drag of the body, caused by a large negative pressure, results in a substantial increase in the body drag. The base drag coefficient of the body is related to the base pressure coefficient [23]

$$
C_{D_{b}}=-p_{b}
$$

where $p_{b}$ is the base pressure coefficient for cylindrical base, determined from Fig. 4 [23] as a function of Mach number.

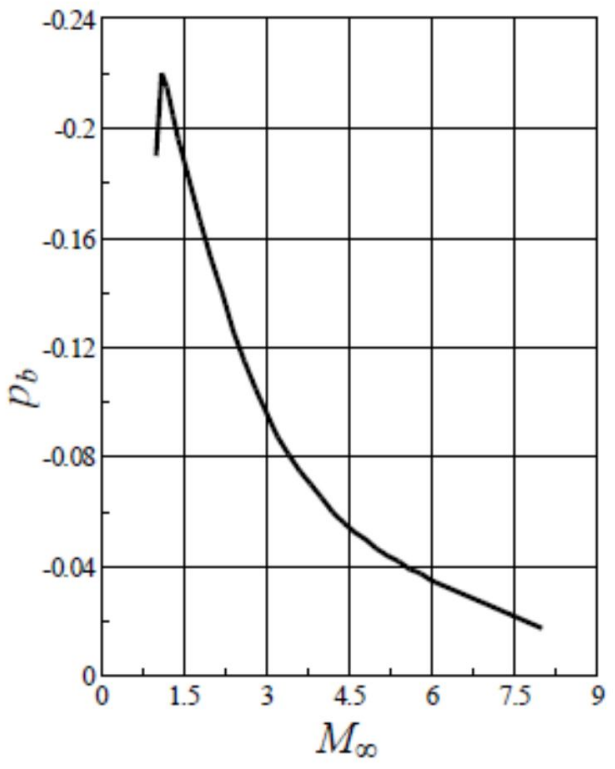

Fig. 4: Base pressure coefficient [23]. 


\subsubsection{Wing-Body Interference Drag}

There exists an amount of drag, which arises from the wing-body interference. In this paper, this contribution is taken into consideration, where the change of drag force coefficient of the wing-body configuration for the body with cylindrical base is given by:

$$
\left(C_{D}\right)_{W B}=C_{W B} \bar{t}_{\text {max }}
$$

where $C_{W B}$ is the wing-body drag force parameter, which is obtained from Fig. 5 [23] as a function of Mach number.

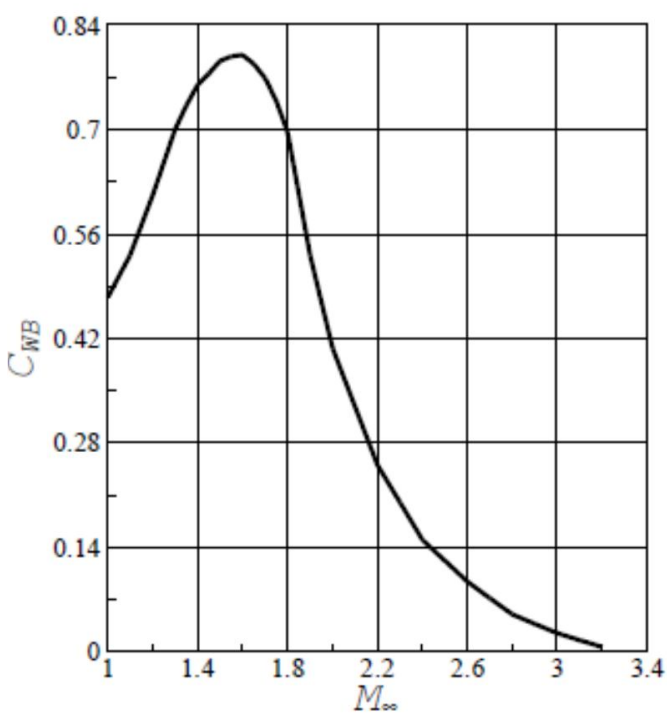

Fig. 5: Wing-body drag [23].

\subsection{Enhancement of Panel Method}

As a case study a low-order panel method is selected. The computer code based in this method is popularly known as the NASA Ames WingBody program. A complete description of the theory and programming details are contained in $[15,16,24]$. In the present work, this panel method, which is able to treat complete configurations, is coupled with the semiempirical methods (above outlined) to enhance the accuracy of drag prediction of flying bodies at supersonic speeds. Both methods were implemented by a computer program and validated against experimental and analytical results.

\subsubsection{Effect of Viscosity}

The methods described in subsections 3.2.1a and 3.2.1b are used to predict the skin friction drag for body and wing respectively. This method is programmed and added to the numerical computer program developed in the present work.

\subsubsection{Base Drag}

The classical panel methods will not capture the effect of base drag. Accordingly, the mathematical model described in subsection 3.2.2 is used to improve the results of drag computation via panel method. 


\subsubsection{Wing-Body Interference Drag}

The amount of drag due to interference between body and wing is also included in the computer program using the mathematical model of subsection 3.2.3.

\section{RESULTS AND DISCUSSION}

The only true test of validity, accuracy, and usefulness of a general computer program, is to compare it with experimental data. Accordingly, the enhanced WingBody computer program has been validated against experimental results published in the literature and with data obtained by other theoretical methods. For this purpose, two configurations have been considered; body-alone and tail-body configurations. Figure 6 shows the details of the dimensions of the selected configurations and the panel model representations used in the numerical program. Figures. 7, 8, and 9 show the comparisons of the experimental data and the results of purely semi-empirical, numerical and modified panel methods.

Figure 7 shows a comparison of the pressure distribution for a body-alone configuration at Mach number of 1.46 and attitudes of $0^{\circ}$ and $180^{\circ}$, where a good agreement was found between the computation and experiment taken from [25], specifically at the nose region.

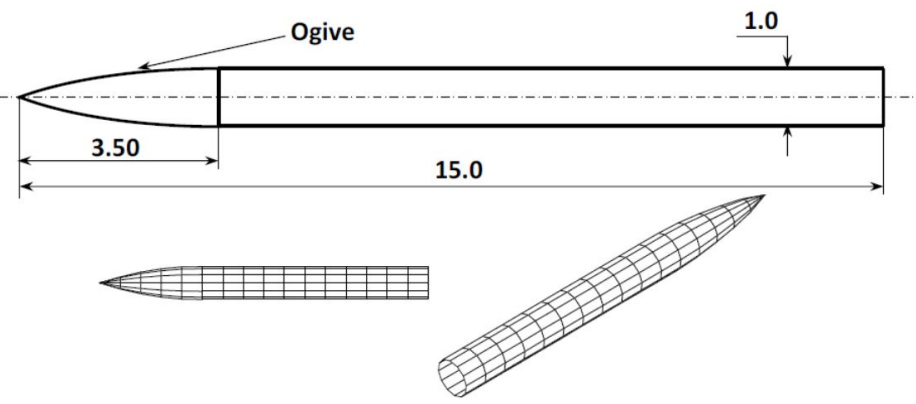

(a) Body-alone configuration.

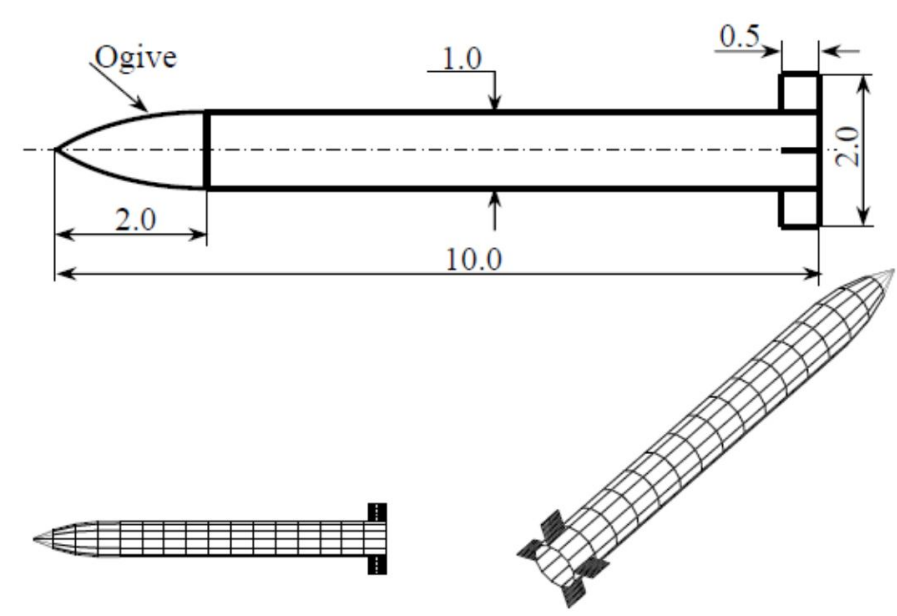

(b) Tail-body configuration.

Fig. 6: The configurations and panel model representations considered for validation [7]. 

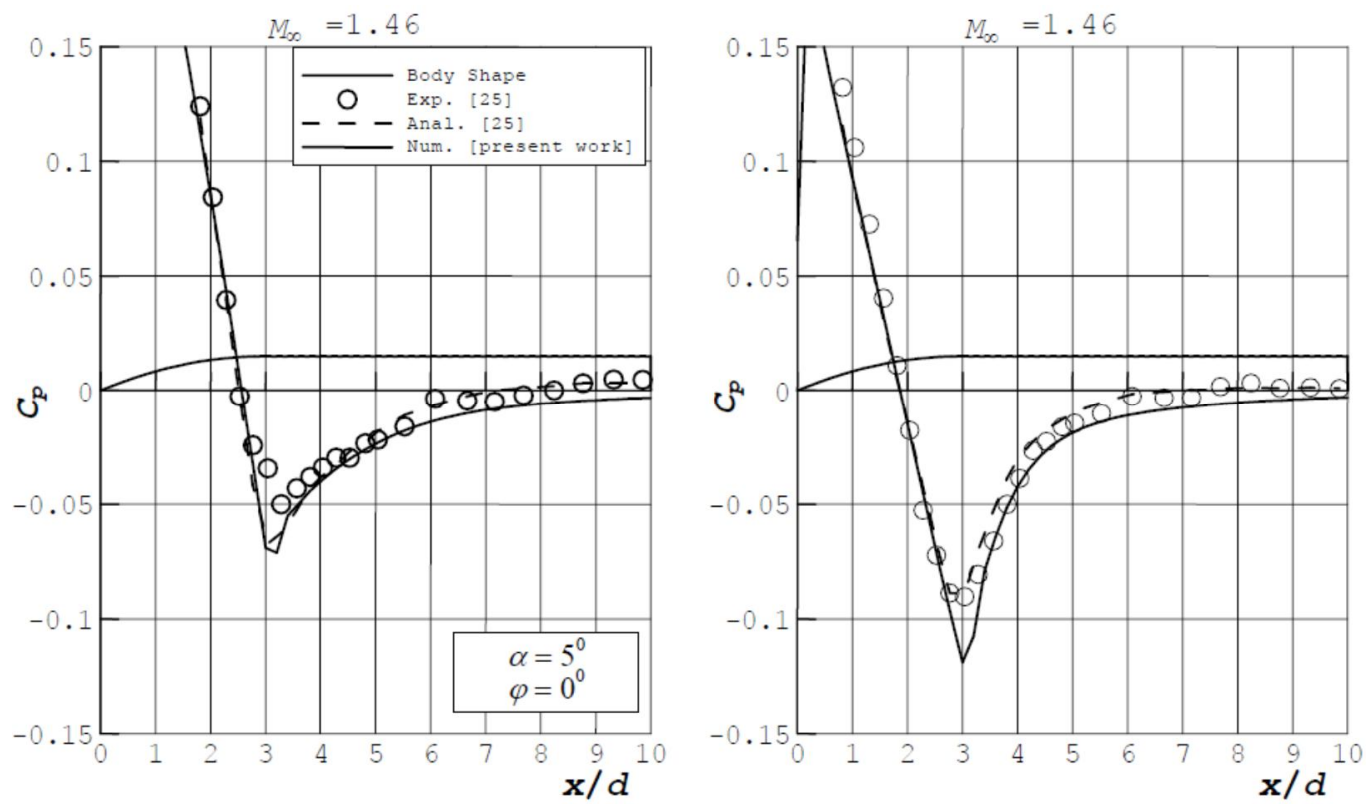

Fig. 7: Pressure Distribution on a body-alone configuration:

Comparison between experiment and theory $\left(M_{\infty}=1.46, \alpha=5^{\circ}\right)$.

Figure 8 shows zero-lift drag coefficient as a function of Mach number and how it compares with experimental data taken from [7]. Two points are worthy of note. First, this figure indicates the significant difference between the drag predictions by the original 'WingBody' and the modified program, where 'WingBody' predicts the drag coefficient within $50 \%$ error, while the modified program reduces this error to $2.3 \%$. This is because the original 'WingBody' is based on a panel method neglects two important components of drag namely skin friction drag and base drag. The second point is that the numerical values of drag coefficient are the closest to the experimental ones, where the purely semi-empirical method used by [6] produces $-11 \%$ average error for $C_{D}$. Thus, the modified numerical method provides better accuracy than the purely semi-empirical method. During the the preliminary design stage of flight-vehicle configurations such accuracy is usually accpeted.

Figure 9 compares the theoretical drag as a function of angle of attack for Mach number 1.3. This figure shows that the agreement is within $-50 \%$ (for the WingBody computer program [24]), $-5 \%$ (for the purely semi-empirical method [6]), and $-8 \%$ (modified WingBody program present method). Despite the fact shown on Fig. 9 that the accuracy of the purely semi-empirical method is better than that of the modified numerical method, the results of the latter are much closer to the experimental compared with panel method. This shows again how efficiently the results have been improved using the modified numerical method. 


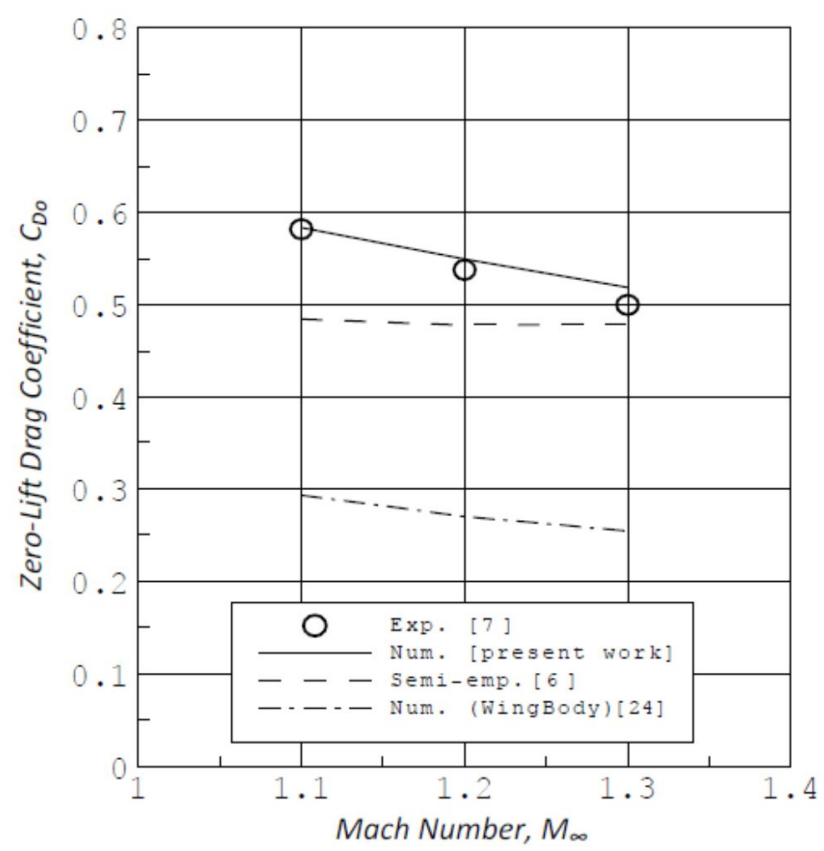

Fig. 8: Zero-lift drag coefficient vs. Mach number. A comparison between experiment and theory $(\alpha=0)$.

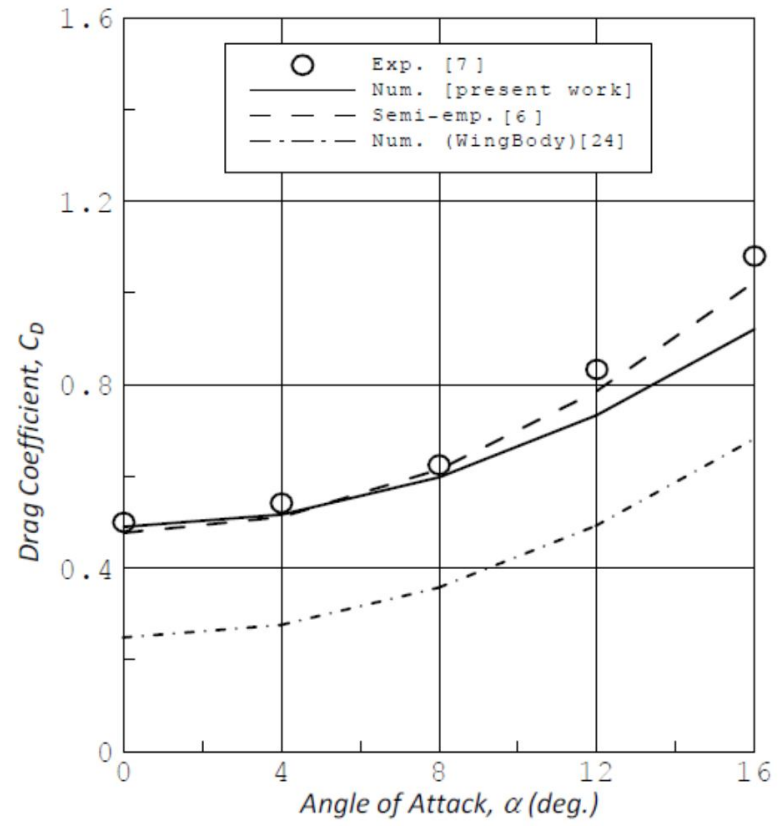

Fig. 9: Drag coefficient vs. angle of attack.

A comparison between experiment and theory $\left(M_{\infty}=1.3\right)$.

Figure 9 also shows that the prediction of drag is more accurate at small angles of attack up to $8^{\circ}$. Above this angle the accuracy is low which is due to not taking into account Reynolds number effect on the body crossflow drag coefficient. In general, accuracy within average of $-4.4 \%$ can be obtained for the enhanced numerical panel method. 


\section{CONCLUSION}

The modified panel method in this work shows higher accuracy in prediction of drag force compared with the classical panel methods. Including the effects of viscosity, base drag and wing-body interference greatly reduced the percentage error in prediction of drag as a function of Mach number from 50\% (classical panel method) to about 5\% (modified panel method).

However, the comparison of the drag force as a function of angle ot attack shows that the accuracy decreases with increasing angle of attack. The modified numerical metod is pereferbale over the purely semi-empirical methods especially if complex geometric configruations are treated.

The proposed method, the numerical and semi-empirical methods give satisfactory results as long as the considered configurations are slender and the angles of attack are small (below stall angle).

In general, the accuracy of the modified numerical program is good and adequate since it is within $\pm 10 \%$, which is acceptable for preliminary design stage of supersonic flying bodies such as projectiles and missiles.

\section{REFERENCES}

[1] A. Jameson, "The evolution of computational methods in aerodynamics." Journal of Applied Mechanics, 50(4b), 1052-1070, 1983.

[2] D. R. Chapman, "Computational aerodynamics development and outlook". AIAA Journal, 17(12), 1293-1313, 1979.

[3] C.R. O'Neill, "Determination of flight stability coefficient using a finite element CFD". Mechanical and Aerospace Engineering, Oklahoma State University, Stillwater, OK 74077, 2000 .

[4] J.S. Letcher Jr., "Convergence of lift and drag predictions by a Morino panel method (VSAERO)." AIAA Journal, 27(8), 1019-1020, 1989.

[5] J., Katz, and A. Plotkin, "Low-speed aerodynamics: from wing theory to panel methods." McGraw-Hill Book Company, Inc., New York, 1991.

[6] A. Sh. Mahdi, "The influence of configuration design on the aerodynamics and stability of SSM at supersonic speeds." Ph.D. Thesis. Al-Rasheed College of Engineering and Science, University of Technology, Baghdad, Iraq, 2005.

[7] F.G. Moore,"Static Aerodynamics of Missile Configurations for Mach 0 to 3." Journal of Aircraft, 12(10), 797-806, 1979.

[8] Larry L. Erickson, "Panel Methods - An Introduction." NASA Technical Paper 2995, 1990.

[9] van Dam C. P. "Recent experience with different methods of drag prediction." Progress in Aerospace Sciences, 35(8), 751-798, 1999.

[10] D. P. Coiro, and F. Nicolosi, "Design of low-speed aircraft by numerical and experimental techniques developed at DPA." Aircraft Design, 4(1), 1-18, 2001.

[11] Mark Voskuijl, Gianfranco La Rocca, Frank Dircken "Controllability of blended wing body aircraft." 26th International Congress of the Aeronautical Sciences, 14-19 Sep 2008, Egan Convention Center, Anchorage, Alaska, USA., 2008 
[12] B. Maskew, "VSAERO A code for calculating the nonlinear aerodynamic characteristics of arbitrary Configurations." NASA CR-4023, 1987.

[13] John J. Bertin, and Michael L. Smith, “Aerodynamics for Engineers”, 3rd Edition, Prentice-Hall International, Inc., 1998.

[14] M. A. Heaslet, L. Lomax, and A.L. Jones, "Volterra's solution of the wave equation as applied to three-dimensional supersonic airfoil problems." NACA Report 889, 1947.

[15] F. A. Woodward, and J.W. Larsen, "A method of optimizing camber surfaces for wing-body combinations at supersonic speeds. Part I - Theory and applications." Doc. D6-10741, Pt. 1 the Boeing Co. NAS2-2282, 1965.

[16] Ralph L. Carmichael, and Frank A. Woodward, "An integrated approach to the analysis and design of wings and wing-body combinations in supersonic flow." NASA TN D-3685, 1966.

[17] J. Kay, W. H. Mason, W. Durham, F. Lutze, and A. Benliel, "Control authority issues in aircraft conceptual design: Critical conditions, Estimation methodology, Spreadsheet assessment, Trim and bibliography." Virginia Polytechnique Institute and State University, Blacksburg, Virginia 24061, 1996

[18] N. F. Krasnov, "Aerodynamics. Part 2 (Methods of Aerodynamic Calculations)." Translated from the Russian Language by G. Leib, Mir Publisher, Moscow, 1985.

[19] S. F. Hoerner, "Fluid-Dynamic Drag.” Horner Fluid Dynamics, Brick Town N. J., 1965.

[20] F. Fankl, V. Voishel "Turbulent friction in the boundary layer of a flat plate in a twodimensional compressible flow at high speeds." NACA Tech Mem. 1053, 1943.

[21] D. E. Hoak, USAF Stability and Control DATCOM. Flight Control Division, Air Force Flight Dynamics Laboratory, Rept. 0410, revised April 1972.

[22] A. A. Lebedev, and L. C. Chernobrovken, "Dynamika poleta bezpilotnich letatelnich aparatov. 'Flight Dynamics of Pilotless of Flight-Vehicles'." Mashen Ctroen, Moscow, 1973.

[23] S. Jankovic, “Aerodynamika Projektila. 'Aerodynamics of Projectiles' Masinski Fakultet, Univerziteta u Beogradu, Belgrade, 1979.

[24] J. E. Brown, A. S. Kawaguchi, and E. LaRowe, "A method of optimizing camber surfaces for wing-body combinations at supersonic speeds. Part I1 - Digital computer program description." Doc. D6-10741, Pt. 11, the Boeing Co., NAS2-2282, 1965.

[25] H. Fushs, and R. Kapp, "Prediction of Dynamic Derivatives". Dornier GmbH, Abt. Bf 20, Postfach 1420, D-7990 Friedrichshafen, FRG, 1987.

\section{NOMENCLATURE}

$\begin{array}{lll}C_{D} & \text { Drag coefficient } & - \\ C_{D b} & \text { Base drag coefficient } & - \\ C_{D f r} & \text { Skin friction drag coefficient } & - \\ C_{D o} & \text { Skin friction drag coefficient } & - \\ \left(C_{D}\right)_{W B} & \text { Zero-lift drag coefficient } & - \\ C_{f} & \text { Wing-body interference drag coefficient } & - \\ C_{W B} & \text { Wing-body drag force parameter } & -\end{array}$




$\begin{array}{lll}c_{M A C} & \text { Wing mean aerodynamic chord } & \mathrm{m} \\ l_{r e f} & \text { Reference length } & \mathrm{m} \\ M_{\infty} & \text { Free-stream Mach number } & - \\ p_{b} & \text { Base pressure coefficient } & - \\ \operatorname{Re} & \text { Reynolds number } & - \\ S_{r e f} & \text { Reference area } & \mathrm{m}^{2} \\ S_{w e t} & \text { Wetted area } & \mathrm{m}^{2} \\ \bar{t}_{\text {max }} & \text { Relative maximum thickness of the wing profile } & - \\ t_{m a x} & \text { Maximum thickness of the wing profile } & \mathrm{m} \\ V_{\infty} & \text { Free-stream velocity } & \mathrm{m} / \mathrm{s} \\ \alpha & \text { Angle of attack } & \mathrm{deg} . \\ \phi & \text { Perturbation velocity potential } & - \\ \varphi & \text { Angle between velocity vector and } x \text {-axis } & \mathrm{deg} . \\ \eta_{t} & \text { Factor for the wing thickness effect } & - \\ v_{\infty} & \text { Free-stream kinematic viscosity } & \mathrm{m}^{2} / \mathrm{s}\end{array}$

